\title{
M蛋白血症を伴った鼻腔 $\mathrm{T}$ 細胞性リンパ腫例
}

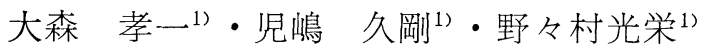 \\ 金地 明星 ${ }^{2)}$ - 豊國 伸哉 ${ }^{3}$

\section{Nasal T-Cell Lymphoma Associated with Double Gammopathy; A Case Report} \\ Koichi Omori, Hisayoshi Kojima, \\ Mitsuharu Nonomura and Shinya Toyokuni \\ (Kyoto University) \\ Myojo Kanaji \\ (Kurashiki Central Hospital)
}

\begin{abstract}
Nasal T-cell lymphoma associated with double gammopathy (IgG and $\operatorname{IgA}$ ) was found in a 78-year-old man with a necrotic tumor in his right nasal cavity. He was treated with radiotherapy and CVP chemotherapy but the lymphoma relapsed in his left nasal cavity 1 year later. He was treated again with the same therapy and is now alive and tumor-free.

Two serum M-components ( $\operatorname{IgG}$ and $\operatorname{IgA}$ ) were detected through his clinical course. To our knowledge, this is the first report of T-cell lymphoma associated with double gammopathy. The significance of $\mathrm{M}$-components in $\mathrm{T}$-cell lymphocytic proliferation remains unclear, but it may be that the $\mathrm{M}$-components appear because of the inappropriate regulation of the T-B immune-response system in the presence of T-cell lymphoma.

Histology in this case is also noteworthy. The first nasal tumor showed granulation and necrotic tissue with plasma cell infiltration; it was diagnosed as non-Hodgkin diffuse lymphoma, mixed type, by surface marker analysis. This indicates that immunohistochemical study is indispensable for the diagnosis of nasal non-healing granuloma with necrosis.
\end{abstract}

Key words : nasal T-cell lymphoma, M-component, double gammopathy, nasal nonhealing granuloma, surface marker

はじめに

覀性リンパ腫に monoclonal gammopathy （以下 $\mathrm{M}$ 蛋白）が合併することは以前から報告 されてきたが1)，ほとんどが B 細胞系腫瘍で，
その腫瘍クローンからM蛋白が産生される機序 が考えられてきた. しかし $\mathrm{T}$ 細胞系腫瘍と $\mathrm{M}$ 蛋 白の合併の報告は極めて少なく, cutaneous T cell lymphoma, Sézary 症候群, 成人 $\mathrm{T}$ 細胞性

1）京都大学医学部耳鼻咽喉科学教室

2) 倉敷中央病院耳鼻咽喉科

3）京都大学医学部病理学教室第一講座 
白血病・リンパ腫（ATLL）などに合併した症 例が報告されているのみで2 〜?，その機序は未 だ明らかではない。

今回我々は $\mathrm{IgA} \boldsymbol{\kappa}$ 型及び $I g G ・ \kappa$ 型の $\mathrm{M}$ 蛋白 を合併した鼻腔 $\mathrm{T}$ 細胞性リンパ腫症例を経験し た. B 細胞系の異常により発現するM蛋白と $\mathrm{T}$ 細胞系腫瘍との合併を説明するのは容易ではな いが今回とれを文献的に考察してみた。また 2 種類の M蛋白 (double gammopathy) の合併に ついても考察を加えた。

本症例は当初壊死性肉芽腫之揨断され, 臨床 的にいわゆる進行性鼻壊疽と考えられていたが， 表面マーカーを調べることで $\mathrm{T}$ 細胞性リンパ腫 の確定診断を得た。鼻腔の壊死性組織の確定診 断には免疫学的検討が重要々考元られたのでと れについても併せて考察を加えた。

\section{症例}

患者：79才，男性.

主訴 : 右血性鼻漏.

既往歷・家族歴：特記すべき事項なし。

現病歴及び経過：昭和 60 年 12 月中旬より右鼻 閉, 右血性鼻漏が現われ昭和 61 年 1 月 7 日に倉 敷中央病院耳鼻咽喉科を受晾した。右下鼻甲介 は表面不整で腫脹しており肉眼的には壊死組織 と思われた。鼻中隔, 左鼻腔, 口蓋に病変は認 められなかった，右下鼻甲介の試切を数回行な ったが，病理組織䛦断はいずれも“肉芽及び壊 死性組織”で, 臨床的にはいわゆる進行性鼻壊

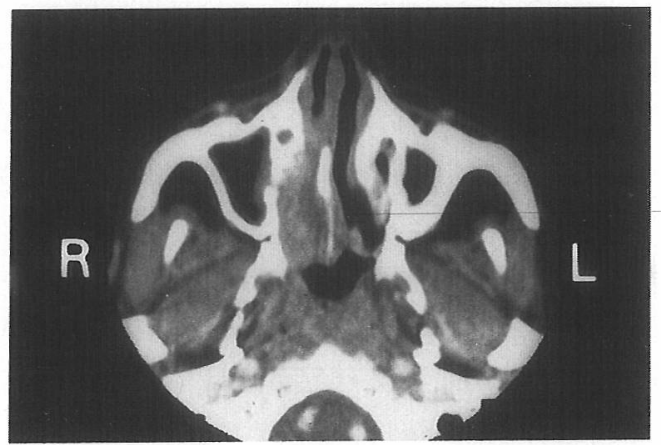

図 1 鼻副鼻腔 CT

右鼻腔から副鼻腔にかけて不均一に造影される 腫瘍陰影がみられる。
疽が疑われた。同年 1 月31日，組織採取と腫瘍 減量とを目的として右デンケル氏手術を施行し た。術中，右鼻腔底部及び右鼻腔外側粘膜に強 い壊死組織を認めたが，骨欠損は見られなかっ た。同年 2 月中旬より左頸部に直径約 $2 \mathrm{~cm}$ の リンパ節が触知されるようになった。

全身所見 : Waldeyer 咽頭輪, 腋下部, 後腹 膜及び鼠径部にはリンパ節腫脹はなく, 肝脾腫 あ認められなかった。体重減少や発熱はなか った。

画像所見 : 術前の CT では右鼻腔及び右上顎 洞内側部に不均一に造影される腫湯陰影が認め られたが，骨破壊像は見られなかった（図1）。 胸部単純 X-P，全身骨 X-P，頭部，腹部及び骨 盤 $\mathrm{CT}$, 腹部 $\mathrm{E}$ cho, $\mathrm{Ga}$ シンチ, 骨シンチ, リン 八゚管造影で全身的な検索を行なったが，右鼻腔 と左頸部以外には病変は認められなかった。

主要検査所見: 末梢血検査成績を表 1 亿示す. 異常所見は，血沈の充進のみであった，末梢血，

表 1 末梢血検査成績

\begin{tabular}{|c|c|c|}
\hline \multirow{11}{*}{ 血液 } & $\mathrm{RBC}$ & $384 \times 10^{4} / \mathrm{mm}^{3}$ \\
\hline & $\mathrm{Hb}$ & $11.7 \mathrm{~g} / \mathrm{dl}$ \\
\hline & Plt & $23.3 \times 10^{4} / \mathrm{mm}^{3}$ \\
\hline & WBC & $4600 / \mathrm{mm}^{3}$ \\
\hline & Seg. & $44.0 \%$ \\
\hline & Band. & $33.0 \%$ \\
\hline & Eos. & $0.0 \%$ \\
\hline & Baso. & $0.0 \%$ \\
\hline & Lymph. & $16.0 \%$ \\
\hline & Mono. & $7.0 \%$ \\
\hline & Aty. Lym. & $0.0 \%$ \\
\hline 血沈 & & $85 \mathrm{~mm} / \mathrm{h}$ \\
\hline 血清 & GOT & $33 \mathrm{IU} / 1$ \\
\hline & GPT & $21 \mathrm{IU} / 1$ \\
\hline & $\mathrm{LDH}$ & $465 \mathrm{IU} / \mathrm{l}$ \\
\hline & Al-p & $112 \mathrm{IU} / \mathrm{I}$ \\
\hline & T.P. & $6.5 \mathrm{~g} / \mathrm{dl}$ \\
\hline & Alb & $53.8 \%$ \\
\hline & $\alpha 1$ & $3.1 \%$ \\
\hline & $\alpha 2$ & $15.4 \%$ \\
\hline & $\beta$ & $12.3 \%$ \\
\hline & $\gamma$ & $15.4 \%$ \\
\hline
\end{tabular}


骨䯣及び尿中の免疫学的検査結果を表 2 亿示す。 免疫グロブリン量，血清補体価，末梢血 T4/ T8 は正常範网内, 血清 HTLV-1 抗体は陰性 であったが，血清免疫電気泳動法で IgA・ $\kappa$ 型 M蛋白及び IgG・ $\kappa$ 型M蛋白が認められた（図 2)，骨䯣には形質細胞の過形成がみられ,䤉素 抗体法で $\operatorname{IgA} ・ \boldsymbol{\kappa}$ 型及び $\operatorname{IgG} ・ \boldsymbol{\kappa}$ 型の胞体内免 疫ブロブリンが認められた。

病理診断：1）初診時の鼻腔組織像；高度の 形質細胞浸潤と軽度のリンパ球浸潤を伴う肉芽 組織で，著明な血管の増生と一部に壊死を認め た。これらの形質細胞は $\kappa, \lambda$ 染色で多クロー

表 2 免没学的検查成績

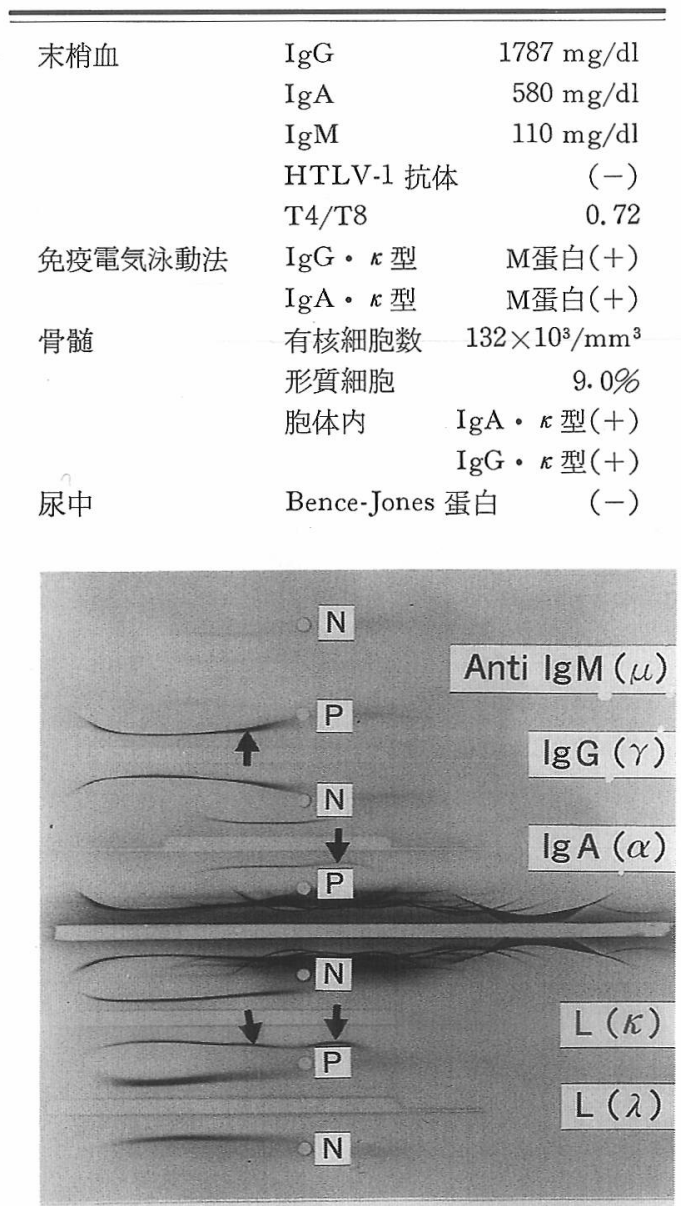

$N$ : 健常人血清 $P$ : 患者血清

図 2 血清免疫電気泳動
ン性を示した(図 3)。2）初診より 1 カ月後の 鼻腔組織像；壊死組織の周囲に，大型及び中型 の核異型を伴うリンパ球のびまん性浸潤性増殖

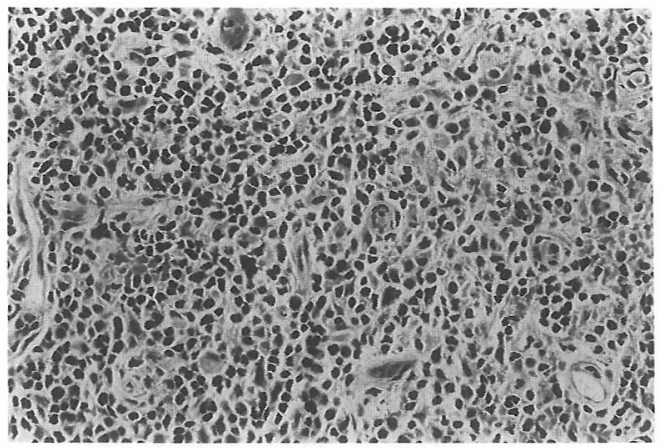

図 3 初期の鼻腔組織像

壊死組織（図右上方）及び高度の形質細胞の 浸潤がみられる。（×200）
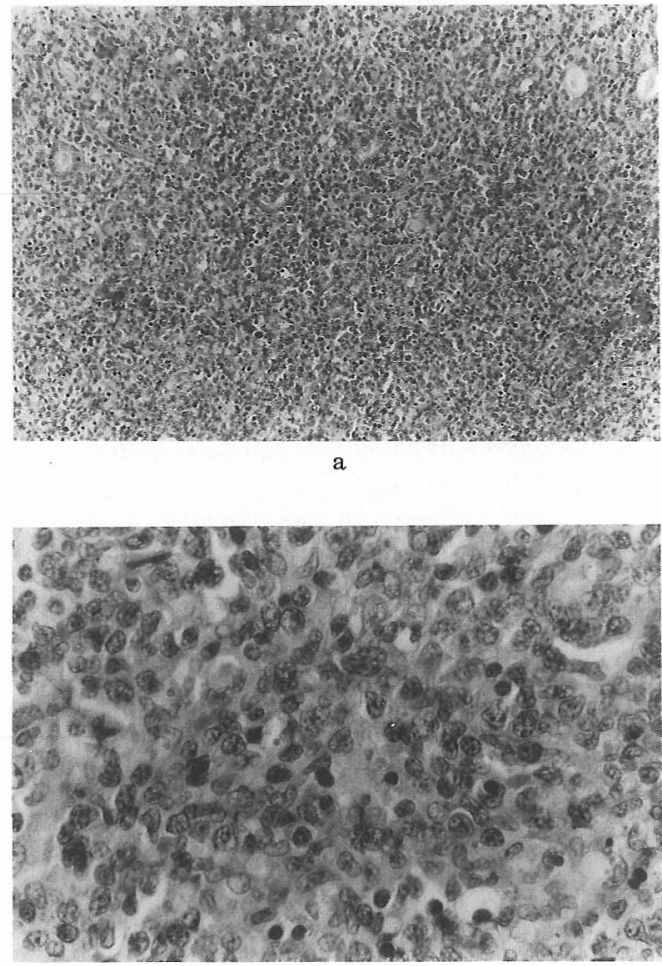

$\mathrm{b}$

図41力月後の鼻腔組織像

大型及び中型の核異型を伴うリンパ球のびまん性 浸潤性增殖を認め悪性リンパ腫びまん性混合型と 晾断された。（a：×100，b：×400） 
を認め, 非ホジキンリンバ腫びまん性混合型と 診断された（図 4)。頸部りンパ節の組織像は 鼻腔組織と同様であった。

免疫組織及び免疫細胞検查 : 鼻腔組織パラフ ィン切片の免疫組織学的検査では, 腫瘍細胞の 表面マーカーは MT-1 (Bio-Science products 社 製， $\mathrm{T}$ 細胞，好中球，組織球で陽性）：陽性(図 5 ), L-26 (Dakopatts 社製，B 細胞で陽性)：陰 性であった。頸部りンパ節についての細胞浮遊 法によるロゼット形成試験及び表面マーカー検 索結果は, 1) E-Rosette : 77\%, EAC-Rosette: $3 \%, 2$ ) CD2 (T11) : 80\%, CD4 (T4 : helper /inducer T cell) : 40\%, CD8 (T8 : suppressor/

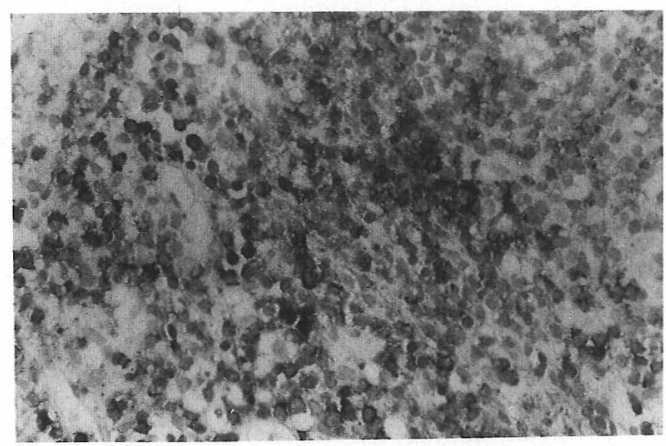

図 5 MT-1 による免疫組織反応

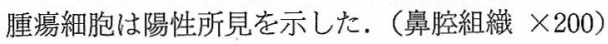

表 3 鼻腔組織及び頸部リンパ節の表面マーカー

1. 䭪瘍細胞の表面マーカー（鼻腔組織） MT-1：陽性 L-26 : 陰性

2. リンパ球表面マーカー（頸部リンパ節） 1）ロゼット形成試験

$\begin{array}{ll}\text { E-Rosette } & : 77 \% \\ \text { EAC-Rosette } & : 3 \%\end{array}$

2) モノクローナル抗体

$\mathrm{CD} 2$ (T11) : $80 \%$

$\mathrm{CD} 4$ (T4) : $40 \%$

$\mathrm{CD} 8$ (T8) : $15 \%$

CD14 (MY4) : $5 \%$

$\mathrm{CD} 10(\mathrm{~J} 5) \quad: \quad 6 \%$

$\mathrm{CD} 21$ (B2) : $0 \%$

HLA-DR (I2) : 62\% cytotoxic T cell)：15\%であった（表 3 ).とれ らの結果から腫瘍細胞は $\mathrm{T}$ 細胞系で, helper/inducer $\mathrm{T}$ 細胞由来と考えられた。

腫瘍細胞染色体分析 : 腫瘍細胞の多くは84 88の染色体数を持ち，その核型はそれぞれの染 色体の tetrasomy やY染色の欠損及び $5 \sim 7$ 個 のマーカー染色体を共通としていた．乙れは異 型細胞の集族が反応性ではなく腫瑒性增殖であ るととを示唆している.

治療：以上より本症例は $\mathrm{T}$ 細胞性リンパ腫と 診断され，病期は Ann Arbor の分類で】期と 考えられた。右鼻腔に $50 \mathrm{~Gy}$ ，左頸部に $40 \mathrm{~Gy}$ の放射線治療及び CVP による化学療法を行い 腫瘍は消失したが， 1 年後に左鼻腔に再発し放 射線治療, 化学療法を追加した。昭和 63 年 12 月 現在寛解中である.

\section{考按}

悪性リンパ腫への $\mathrm{M}$ 蛋白の合併は，ほとんど が B 細胞性リンパ腫でその腫瘍クローンから $\mathrm{M}$ 蛋白が産生される機序が推定されているが，T 細胞系腫瘍之M蛋白の合併の報告は少なく，ま たその機序は不明である. Kövary ら ${ }^{33}$ は，T細 胞性腫瘍之される Sézary 症候群13例中 4 例に M蛋白の合併を認め，その原因として $\mathrm{T}$ 細胞を 介した免疫系の障害を示唆し，Ferme ら4は， Sézary 細胞そのものが正常B 細胞に作用する 機構を推察した。本邦では北らら゙，末期に M蛋白が出現した $\mathrm{T}$ 細胞性リンパ腫を報告し， T細胞による抗体産生機構の破綻がその原因 と考え，上平ら6)は $\mathrm{M}$ 蛋白を前駆症状とする ATLL 症例を示し, HTLV-1 virus 感染による 免疫機構の失調を推察した。

$\mathrm{T}$ 細胞の B 細胞系への影響については，現在 までに，HTLV-1 で株化されたT細胞株 ${ }^{82} や$ T-hybridoma ${ }^{9}$ の産生する B 細胞增殖因子 $(\mathrm{BCGF})$ や B 細胞分化因子 (BCDF) などの液 性因子が B細胞の増殖，分化に作用するととや， M蛋白を合併した OKT8 陽性（suppressor/ cytotoxic） T細胞性リンパ腫の腫瘍細胞培養上 清が, in vitro で患者 B 細胞に IgM の産生を誘 
導する活性を持つことが示されている77.

本症例では 2 種類の M蛋白が合併しており， これは，B 細胞系の腫瘍性增殖と考えるよりも， $\mathrm{T}$ 細胞の影響で抗体産生機構の乱れが生じて 2 次的に M蛋白が出現したとする考えを支持す ると考えられた．Ｍ蛋白血症のうち double gammopathy の頻度は $2.5 \%$ 程度といわれ ${ }^{10)}$, 悪性リンパ腫に合併した症例屯報告されている

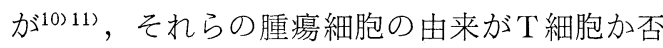
かの記載はなく，我々の検索では，double gammopathy を合併した $\mathrm{T}$ 細胞性リンパ腫症例の 報告は見られない。

さらに，初期の組織像における形質細胞の増 生は， $\kappa, \lambda$ の染色で多クローン性を示したので 腫瘍性増殖ではなく反応性増殖と考えられ，乙 の点からも，本症例の $\mathrm{M}$ 蛋白は腫瘍化 $\mathrm{T}$ 細胞 が B 細胞の分化に作用して生じたものと考えら れた。

以上より本症例は, “ $\mathrm{T}$ 細胞性リンパ腫への $\mathrm{B}$ 細胞系腫瘍の合併”之する考えは否定的であり， $\mathrm{T}$ 細胞系の異常が $\mathrm{B}$ 細胞系の免疫グロブリン産 生機構に乱れを生じさせ， $\mathrm{T}$ 細胞系の制御から 離れた $\mathrm{B}$ 細胞クローンの増殖により $\mathrm{M}$ 蛋白が出 現したものと考えられた。

また，本症例では病理組織診断が問題となり， 当初, 鼻腔組織は肉芽及び壊死性病変と診断さ れ，臨床所見と併せて進行性鼻壊疽と考えられ た. いわゆる進行性鼻壊疽の病態, 病理組織学 的分類は現在なお確立されておらず，広義には， 悪性リンパ腫, Wegener 肉芽腫, 悪性組織球症 及び壊死性肉芽腫が含まれるが，病理学的に特 徵の無い “壊死性肉芽腫”の帰属が問題となる. 進行性鼻壊疽症例の組織の見直しでその約 6 割 が悪性リンパ腫やその疑いと診断された報告 ${ }^{12}$ や，モノクローナル抗体による表面マーカーの 検索で，今まで壊死性肉芽腫と診断され臨床 的には進行性鼻壊疽とされてきた症例が悪性り ンパ腫であった報告が多くみられるようにな り ${ }^{13)}$ 15)， いわゆる進行性鼻壊疽の大部分が悪 性リンパ腫であり，残りが Wegener 肉芽腫，
悪性組織球症と考えるのが妥当ではないかと推 察される．いずれにしろ進行性鼻壊疽を議論す るには表面マーカーの検索が不可欠であり, 本 症例でも頻回の生検之腫瘍細胞の表面マーカー 検索で $\mathrm{T}$ 細胞性悪性リンパ腫との確定診断を得 るに至った。鼻腔なよ゙リンパ節外の壊死性組織 の病理診断は困難なととがあり, 免疫学的検討 が重要と考えられた。

\section{まとめ}

$\operatorname{IgA} ・ \boldsymbol{\kappa}$ 型, $\operatorname{IgG} ・ \boldsymbol{\kappa}$ 型の 2 種類の $\mathrm{M}$ 蛋白 (double gammopathy) を伴った鼻腔 $\mathrm{T}$ 細胞性 リンパ腫を報告した。本症例の $\mathrm{M}$ 蛋白血症は，

$\mathrm{T}$ 細胞性リンパ腫における $\mathrm{T}$ 細胞の抗体産生調 節機構の異常を示唆するあのと考えられた。ま た, いわゆる進行性鼻壊疽症例には免疫学的検 討が必須と考えられた。

本論文の要旨は第 48 回耳鼻咽喉科臨床学会で口演 した.

本稿を終えるにあたり, 御校閱を賜った京都大学医 学部耳鼻咽喉科学教室本庄 嚴教授に梁謝致します. また本研究に御助言頂いた山边博彦助教授 (京都大学 医学部付属病院病理部), 福原資郎先生, 土井章一先 生 (京都大学医学部第一内科) 飞感謝致します.

\section{参考文献}

1) Alexanian R : Monoclonal gammopathy in lymphoma. Arch Intern Med $135: 62 \sim 66,1975$.

2) Broder $\mathrm{S}$ and Bunn AP : Cutaneous $\mathrm{T}$ cell lymphomas. Seminars in Oncology $7: 310 \sim 331$, 1980.

3) Kövary PM, Suter L, Macher E, et al : Monoclonal gammopathies in Sézary syndrome; a report of four new cases and a review of the literature. Cancer 48 : 788 792, 1981.

4) Ferme F, Andrieu JM, Flandrin G, et al : Sézary syndrome occurring ten years after monoclonal gammopathy treated for four years by chlorambucil. Leukemia Research 5 : 169 171, 1981.

5 ) 北 堅吉, 高月 清, 内野治人, 他 : 末期にM成 分の出現した T-cell Lymphoma の 1 剖検例. 臨 床血液 $22: 1809 \sim 1814,1981$. 
6 ）上平 憲, 木下研一郎, 市丸道人：良性M蛋白血 症の経過中に発病した成人 $\mathrm{T}$ 細胞白血病・リンパ 腫の 2 症例. 臨床血液 $25: 1133 \sim 1137,1984$.

7 ）石橋和明, 花田修一, 橋本修治：M蛋白血症を合 併した OKT-T 細胞リンパ腫の 1 例一液性因子の 検討一. 臨床血液 $27: 758 \sim 763 ， 1986$.

8 ) Shimizu K, Hirano $T$, Ishibashi $K$, et al : Immortalization of BGDF (BCGF II)-and BCDF-producing $\mathrm{T}$ cells by human $\mathrm{T}$ cell leukemia virus (HTLV) and characterization of human BGDF (BCGF II). J Immunol 134 : 1728 1733, 1985.

9) Okada M, Sakaguchi N, Yoshimura N, et al : B cell growth factors and B cell differentiation factor from human $\mathrm{T}$ hybridomas. J Exp Med $157:$ 583 590, 1983.

10) Riddle $S$, Traczyk $Z$, Paraskevas F, et al : The double gammopathies. Medicine $65: 135 \sim 142$, 1986.

11) Guarner J, Austin GE, Nassar VH, et al :
Biclonal gammopathy (IgG $\kappa$ and $\operatorname{IgG} \lambda$ ) in a patient with Non-Hodgkin's lymphoma. Arch Pathol Lab Med 110 : 445 448, 1986.

12）犬山征夫，堀内正敏，甲能直幸，他：進行性鼻壊 疽に対する臨床的考察. 耳喉 $53: 393 \sim 401$, 1981.

13）形浦昭克：進行性鼻壊疽における免疫組織学的検 討とその病態. 鼻副鼻腔 19:15～16， 1980.

14) Ishii $Y$, Yamanaka N, Ogawa $K$, et al : Nasal $\mathrm{T}$-cell lymphoma as a type of so called "lethal midline granuloma”. Cancer $50: 2336 \sim 2344$, 1982.

15）福田 諭, 寺山吉彦, 安住典夫, 他：モノクロー ナル抗体にて検索した進行性鼻壊疽の 1 例. 耳喉 $55:$ 509 514, 1983.

\footnotetext{
(原稿採択 : 平成元年 5 月 26 日 別刷請求先 : 大森孝一

干606 京都市左京区聖護院川原町54 京都大学医学部耳鼻咽喉科学教室
} 